ACTA UNIVERSITATIS LODZIENSIS

FOLIA LITTERARIA POLONICA 5(35) 2016

http://dx.doi.org/10.18778/1505-9057.35.05

Rafał Leśniczak*

\title{
The Persuasiveness of a Message and the Problem of Legitimacy
}

\section{Introduction}

The aim of the article is to provide an answer to whether using linguistic, persuasive measures in political communication is a rational basis for legitimisation of the democratic political system. In order to do so I shall adduce Jürgen Habermas's ${ }^{1}$ concept of the "ideal speech situation". The author of the text intuitively, almost a priori, assumes that political communication, by definition, consists of persuasive elements. The aim of the research is, thus, not to prove that persuasive elements are included in politicians' speeches: this should be obvious, just like a rhetorical question which one does not have to answer.

For my analysis I have chosen the following speeches by Italian politicians: the Prime Minister, Matteo Renzi's, and Beppe Grillo's, leader of the Five Star Movement political party (MoVimento 5 Stelle), which took place in the European Parliament in Strasbourg on $2^{\text {nd }}$ July 2014; Grillo's speech summarising the year 2014 (31 ${ }^{\text {st }}$ December 2014), as well as Silvio Berlusconi's speech dated $28^{\text {th }}$ November 2013, which was his last speech as a member of the Senate ${ }^{2}$. The accompanying

* Dr., e-mail: rafalles@vp.pl; Cardinal Stefan Wyszyński University in Warsaw, Institute of Media Literacy and Journalism; ul. Dewajtis 5, 01-815 Warszawa.

${ }^{1}$ See: J. Habermas, "Vorstudien und Ergänzungen zur Theorie des kommunikativen Handelns", Frankfurt am Main 1984, pp. 177-178.

${ }^{2}$ The analysed speeches are available online:

- the Prime Minister M. Renzi's speech in the European Parliament in Strasbourg, 2.07.2014, http://archivio.internazionale.it/news/unione-europea/2014/07/02/il-discorso-integrale-di-matteorenzi-al-parlamento-europeo [access: 4.11.2015];

- B. Grillo's speech in the European Parliament in Strasbourg, 2.07.2014, https://www.youtube. com/watch? $\mathrm{v}=$ cbkaEeG721Y [access: 4.11.2015];

- B. Grillo's speech summarising the year 2014, 31.12.2014, http://www.beppegrillo.it/videos/0 s49orvgm.php [access: 4.11.2015], http://www.repubblica.it/2004/a/sezioni/politica/festaforza/ discesa/discesa.html [access: 4.11.2015];

- S. Berlusconi's speech as a senator, 28.11.2013, https://www.youtube.com/watch?v=go4FPwf0aVI [access: 4.11.2015]. In the following analysis Renzi's speech in the European Parliament is be 
circumstances of these speeches are crucial and they are connected with a period of time when Italian public opinion was concentrated on the economic crisis, and increasing international debt, as well as the increasing unemployment rate, especially among young people. The speeches of the Italian Prime Minister Renzi and of the leader of the Five Star Movement in Strasbourg took place at the very beginning of Italy's six-month presidency of the Council of the European Union, and they fall within the ambit of the problems which concern Europe ${ }^{3}$. Grillo's speech from the end of 2014 also corresponds with the context. Berlusconi's speech from 2013 closes an important stage of his political career as a member of the Senate.

Why were these representatives of Italian politics chosen for this analysis? For many years the author has been interested in the issues connected with Italian political communication. It is a country with a long history of democracy, successor of the ancient rhetoricians of the Roman Empire. Several years spent in Italy allowed him to look "more closely" at the techniques of Italian political communication. Of course, in order to find the correct answer to the exploratory question posed at the beginning of the article, one could choose a different country, different speakers and different discourse circumstances.

The politicians, whose speeches are the subject of the linguistic analysis in this article, are some of the most important personalities in Italian politics. A ranking published in an online version of the "Panorama" weekly was used as the criterion of importance. In the ranking Renzi, Berlusconi and Grillo are at the top of the "10 most important Italian politicians of 2014" category 4 .

Since $22^{\text {nd }}$ February 2014, Matteo Renzi has been the Prime Minister of Italy. His political activity started in the $1990^{\text {s. }}$. He is associated with the Italian People's Party, The Daisy (La Margherita) political party, and he is the leader of the Democratic Party. From 2004 to 2009 he was the President of the Province of Florence, and from 2009 to 2014 he was the Mayor of Florence 5 .

Beppe Grillo is 67 years old, an Italian comedian, actor, the founder and leader of the euro-sceptic Five Star Movement political party, which is famous for its populist, ecological and anti-corruption statements ${ }^{6}$. He runs a blog, beppegrillo.

marked as Renzi_1, Grillo's speech in the European Parliament as Grillo_1, and his speech summarising the year 2014 as Grillo_2. S. Berlusconi's last speech as a senator is marked as Berlusconi_1.

${ }^{3}$ See: I. Dziurlikowska, „Włoska prezydencja pod znakiem rozwoju”, http://www.uniaeuropejska.org/wloska-prezydencja-pod-znakiem-rozwoju [access: 4.11.2015].

${ }^{4}$ See: C. Daconto, "I 10 politici più importanti del 2014", http://www.panorama.it/news/ politica/i-10-politici-piu-importanti-2014/ [access: 4.11.2015].

${ }^{5}$ See: "Matteo Renzi, la mia storia. Chi sono", http://www.matteorenzi.it/chi-sono/ [access: 4.11.2015].

${ }^{6}$ See: "Chi c'è dietro Beppe Grillo? Ritratto di Casaleggio, lo stratega 5Stelle", http://www. iltempo.it/politica/2012/10/01/chi-c-e-dietro-beppe-grillo-ritratto-di-casaleggio-lo-stratega5stelle-1.3130 [access: 11.02.2015]; "Beppe Grillo: humorysta, bloger, polityk", http://pl.euronews. com/2012/05/22/beppe-grillo-humorysta-bloger-polityk/ [access: 4.11.2015]. 
it, which, according to the British "The Guardian", is one of the most influential blogs in the world?

Silvio Berlusconi is 79 years old, an Italian politician, the leader of the Forza Italia political party, and has been the Prime Minister of Italy three times (1994-1995, 2001-2006, 2008-2011). He is considered one of the richest Italian citizens. He is the owner of, among other things, Banca Mediolanum conglomerate, Mondadori national publishing company and AC Milan football club ${ }^{8}$.

\section{The "ideal speech situation" according to Habermas}

Jürgen Habermas - a German sociologist and philosopher - points out that activities concerning political communication allow the achievement of a consensus and create common definitions in a democratic country. According to the scholar, in democratic systems the public political discourse should aim at the cooperation of the participants in the debate, and at a harmonious collaboration in achieving important social goals, at the same time, the commonness of participating in political communication is also crucial ${ }^{9}$. It should be emphasised here, that it is largely thanks to the mass media that citizens of countries from all over the world can participate in politicians' public speeches. Habermas proposes a certain passus from a technical rationality to the communicational one for democratic countries. However, what stems form the communicational reality is the definition of the true values and aims of a specific community ${ }^{10}$. The diversity of political opinions, thanks to the political discussion, should result in reaching the appropriate consensus. The reflection of the citizens upon the state affairs is a modern Areopagus of the communicational activities. Of course, there is an open question whether modern politicians in their public speeches care if Habermas's concept finds its reference in the communicational acts created by them. The "ideal speech situation" described by the German sociologist is one which fulfils several conditions, according to which the discourse should be conducted in order to be perceived as a rational basis for the legitimisation

7 “The world's 50 most powerful blogs", http://www.theguardian.com/technology/2008/ mar/09/blogs [access: 4.11.2015].

${ }^{8}$ See: R. Capek-Habekovič, S. Palaich, “Parola a te!”, Heinle Cengage Learning, Boston 2009, p. 47; "Silvio Berlusconi", http://ludzie.wprost.pl/sylwetka/Silvio-Berlusconi/ [access: 4.11.2015].

${ }^{9}$ See: J. Fras, „Komunikacja polityczna. Wybrane zagadnienia gatunków i języka wypowiedzi”, Wydawnictwo Uniwersytetu Wrocławskiego, Wroclaw 2005, pp. 242-244.

${ }^{10}$ See: P. Baciak, „Internet - Agora XXI wieku? Rozważanie w świetle teorii demokracji deliberatywnej autorstwa Jürgena Habermasa”, Global Media Journal - Polish Edition 2006, No. 2 (2), pp. 136-139, http://globalmediajournal.collegium.edu.pl/artykuly/jesien\%202006/Baciak-Internet\%20-\%20Agora\%20XXI\%20wieku.pdf [access: 4.11.2015]. 
of the democratic political system. These conditions are: equality between the discourse partners, complete exposure of the deliberation processes, temporary abandonment of power and domination relations, and freedom to choose the topic of the discussion ${ }^{11}$.

In this article, the author assesses if these conditions were fulfilled in the public discourses of the politicians or not. He also evaluates the influence of the means of persuasion used on achieving the above mentioned conditions, which decide about acknowledging - or not - a politician's speech as a rational basis for legitimisation of the democratic political system. Habermas's theory, which is only a theoretical concept, indicates the existing references between the communicational acts and politics.

The individual intellectual and moral predispositions of the speaker should also be taken into consideration in the objective assessment of the fulfilment of Habermas's conditions. Ancient masters of the word, among which were Aristotle, Cicero and Quintilian, emphasised in their works the significance of the speaker's ethos. In Nicomachean Ethics the philosopher born in the city of Stagira, points out that virtue is "a permanent disposition by which man becomes good and can properly perform his functions and duties"12. The philosopher also enumerates other crucial qualities like the speaker's moderation, discretion and bravery ${ }^{13}$. If, according to Aristotle, the orator were to misuse the truth, it would insult the recipient, as well as contradict their own rationality. Cicero states that a good orator is the one who is a competent person, who speaks about issues he is familiar with, and in connection with which they have an appropriate education. Apart from that, the Roman writer and rhetorician claims that the speaker should be a wise man and should represent proper virtues ${ }^{14}$. Quintilian in his work Institutes of Oratory (Institutionis oratoriae) emphasises that "a citizen, who is qualified for the management of public and private affairs, and who can govern communities by his counsels, settle them by means of laws, and improve them by judicial enactments, can certainly be nothing else but an orator" ${ }^{\prime \prime}$.

${ }^{11}$ See: J. Habermas, op. cit.; P. Baciak, op. cit.; A. Gimmler, "Deliberative Democracy, the Public Sphere and the Internet", Philosophy \& Social Criticism 2001, Vol. 27, pp. 21-39; M. Żardecka-Nowak, „Demokracja deliberatywna jako remedium na ponowoczesny kryzys legitymizacji władzy”, Teka Komisji Politologii i Stosunków Międzynarodowych. Polska Akademia Nauk Oddziat w Lublinie 2008, Vol. III, pp. 29-40, http://www.pan-ol.lublin.pl/wydawnictwa/TPol3/Zardecka. pdf [access: 4.11.2015].

${ }^{12}$ Arystoteles, „Etyka nikomachejska”, as cited in: Aristotelis, "Ethica Nicomachea”, recognovit F. Susemihl, Teubner, Lipsiae 1880, H1106a 20-23.

${ }^{13}$ Arystoteles, „Etyka wielka”, in: idem, „Dzieła wszystkie”, Vol. 5, transl. D. Gromska, Wydawnictwo Naukowe PWN, Warsaw 1996, pp. 338-344.

${ }^{14}$ See: M.T. Cyceron, „O mówcy”, transl. B. Awianowicz, Wydawnictwo Antyk, Warsaw 2011, p. 97.

${ }^{15}$ Kwintylian, „Kształcenie mówcy. Księgi I, II i X”, transl. and ed. M. Brożek, Ossolineum, Wroclaw 1951, p. 10. 
This mention of the ancient models of good orators proves that it is not only the appropriate usage of linguistic measures of persuasion in assessment of the relations between the persuasiveness of the communication and the problem of power legitimisation that matters. It is also the speaker's ethos. It is, thus, crucial to know not only what a politician said and how they did it, but also who is the sender of the communication. It will be helpful in the analysis of the mentioned speeches.

\section{Analysis of the selected speeches}

\section{Linguistic measures of persuasion - rhetorical figures}

At the beginning, it should be specified what is understood as "persuasion". In order to do that I shall use a definition by Walery Pisarek - a notable Polish linguist and expert on the press. He claims that persuasion is

An endeavour to exert influence on beliefs, opinions, attitudes, spirits, and the recipient's behaviour by means of communications (verbal and non-verbal) and the argumentation contained in them (rational and emotional), which is a result of a selection of the body matter and form ${ }^{16}$.

Persuasion, in contrast to manipulation, takes place when rational and true information is conveyed. Manipulation consciously and intentionally distorts and fabricates it. According to Robert Dahl - an American sociologist and political scientist - persuasion is the dialectic of the modern reality, whereas manipulation is pretence or a $l i e^{17}$.

The persuasiveness of the communication is the speaker's means to influence the recipient's actions. There are various techniques of persuasiveness in communication. These are the techniques I noticed in my analysis: using directive speech formulas and expressions of a duty-imposing nature; the volitional character of an utterance; and rhetorical figures (for example, emphasis, enumeration, simile, repetition, confession, rhetorical question).

The directive speech formulas, for example, have to, must, one needs to, express the duty of performing an action in which the listener gets involved. Here, I quote a few examples of these forms, which can be found in the analysed speeches:

${ }^{16}$ W. Pisarek, „Perswazja - jak ją widzą, jak ją piszą”, in: „Język perswazji publicznej”, ed. K. Mosiołek-Kłosińska, T. Zgółka, Wydawnictwo Poznańskie, Poznan 2003, p. 15.

${ }^{17}$ See: M. Nieć, „Komunikowanie społeczne i media. Perspektywa politologiczna”, LEX Grupa Wolters Kluwer, Warsaw 2010, p. 229. 
Renzi_1 (10:22) 18 "It has to be a positive fact". (Questo deve essere un fatto positivo.) Renzi_1 (18:45) "We have to do this for the sake of our children". (Lo dobbiamo ai nostrifigli.)

Berlusconi_1 (0:22) "We have to stay in the game. We must not break, even if the leader of centre-right politics is no longer a senator". (Dobbiamo restare in campo. Non disperiamoci se il leader centrodestra non è più senatore.)

Grillo_1 (09:18) "You have to make a leap of imagination". (Bisogna fare un salto di immaginazione.)

Grillo_1 (11:38) "You have to sit down and start thinking". (Qui bisogna sedersi ed incominciare a ragionare.)

Grillo_1 (14:31) "It takes a psychiatrist to understand that". (Ci vuole un psichiatra per capire.)

Grillo_1 (17:03) "You have to sit down and rethink in what kind of a world you want to live”. (Qui bisogna sederci e ripensare in che mondo vogliamo vivere.)

Grillo_1 (20:08) "We have to take it out". (Dobbiamo tirare fuori.)

Grillo_2 (02:39) "That is why you have to speak in whispers". (Ecco, perché bisogna parlare sottovoce.)

The first person plural verbs, the personal pronoun we and the possessive pronoun our in the language of politicians are to identify the listeners with the speaker in their beliefs and views. This technique of persuasion can be noticed in the following examples:

Renzi_1 (02:05): "What is today's debate over European politics after the crisis we have all experienced and are still experiencing?" (Che cos'è oggi il dibatto sulla politica europea dopo la crisi che tutti abbiamo vissuto e che la crisi che stiamo vivendo?) Renzi_1 (03:11) "If we stop for a second to consider, let us imagine...". (Se ci fermiamo un secondo a riflettere e immaginiamo...)

Renzi_1 (04:27) "I do not think we can underestimate the financial issues". (Non credo che possiamo sottovalutare la questione finanziaria..)

Renzi_1 (06:35) "We were using the language of truth". (Noi abbiamo parlato nel linguaggio di verità.)

Renzi_1 (07:00) "We know that, first of all, we have to ask ourselves if we have the strength to change in order to be credible". (Noi sappiamo che prima di tutto dobbiamo chiedere a noi la forza di cambiare se vogliamo essere credibili.)

Renzi_1 (09:53) "For this to happen ... we should be able to vigorously oppose the simplifications of our institutions and of European life". (Perché questo accada ... dovremmo essere capaci di affrontare con forza la questione della semplicità delle nostre istituzioni e della vita europea.)

${ }^{18}$ The numbers in brackets indicate the precise location of the quoted fragment of the speech on the YouTube website. 
Renzi_1 (10:12) “We want to build together”. (Vogliamo costruire tutti insieme.)

Also the volitional character can be noticed in some of these utterances:

Renzi_1 (02:12): "Let me explain this by means of a joke". (Lasciatemelo dire con una battuta.)

Renzi_1 (02:24): “Can I say this with the utmost concern?" (Posso dirlo con l'estrema preoccupazione?)

Renzi_1 (14:30) "Let me tell you a conclusion". (Lasciatemelo dire concludendo.)

It is worth highlighting that the utterances which address the human will incline the listener to adopt the proposed content of the discourse, but not by means of institutional power. One cannot speak here about an advantage of the sender over the receiver of the communication. A request is not an order, the recipient is more willing to comply with the first than to carry out the latter. A request, as an act of speech, obliges in the deontological and moral sphere, and not in the institutional one. The orator who uses a request appeals to the listener's sensitivity, at the same time showing them respect and trust, as well as holding them in high regard. The recipient of the communication knows that they do not act under compulsion but out of free will. It also results in the recipient's peculiar urging not to fail the trust of the sender of the communication ${ }^{19}$. The volitional character can be expressed by means of expressions like please, I would like to, I wish:

Renzi_1 (08:37) "We would like to say this with great serenity". (Vogliamo dirlo con grande serenità.)

Renzi_1 (04:23) "Let me be clear, please". (Vorrei essere chiaro.)

Renzi_1 (05:36) "I would like to say it with great clarity and conviction". (Voglio dirlo con grande chiarezza e convinzione.)

Renzi_1 (06:04) "I am also trying to say". (Provo anche a dire.)

Grillo_1 (07:16) "I would like to know who should be held responsible for this hospitality". (Voglio sapere chi si deve accollare il peso di questa accoglienza.)

Grillo_1 (10:16) "I want people to understand that". (Voglio far capire alla gente.) Grillo_2 (08:01) "I don't want to impose anything, please, judge for yourselves. I want to leave you in peace, although I would like to read you a short parable, lets call it a parable". (Non voglio imporvi nulla, giudicate voi. Voglio lasciarvi in modo sereno, però, voglio leggervi una piccola parabola, chiamiamola parabola.)

${ }^{19}$ See: D. Zdunkiewicz, „Językowe środki perswazji w homiliach (na przykładzie tekstów Jana Pawła II)”, in: „Język a kultura”, Vol. 4 „Funkcje języka i wypowiedzi”, ed. J. Bartmiński, R. Grzegorczykowa, Wiedza o Kulturze, Wroclaw 1991, p. 151. 
The persuasiveness of the communication presents itself in imperative sentences, which take the form of duty-imposing sentences. A politician who uses such a sentence creates a sense of community, of closeness with the listener, for example: Renzi_1 (05:02) "Our great challenge now is to find the soul of Europe". (La nostra grande sfida oggi è ritrovare l'anima dell'Europa.)

Emphasis, that is the exaggerated emotionality of an utterance but also the stress put on some sentences, words or syllables, which exposes their meaning ${ }^{20}$, can be noticed in the following quotations:

Renzi_1 (01:11) "Because of all these reasons I am happy... (applause) I am happy and honoured to represent my country. (Per tutti questi motivi dunque sono felice... (applauso) sono felice e onorato di rappresentare il mio Paese.)

Grillo_1 (09:35) "I came here to talk to you seriously". (Sono venuto qua per parlarVi seriamente.)

Grillo_1 (27:25) "I would like to give this Lady a round of applause. Dear Lady, bravo, bravo! (Vorrei fare un applauso a questa Signora. Cara Signora, bravo, bravo!)

Enumeration is listing in the text the following elements of a certain entity; it is used to strengthen the utterance:

Renzi_1 (03:20) "When we think about the connection between Greece and Italy, we do not think about things which are extraordinary, stunning and full of suggestions, like the relations between Anchises and Aeneas, Pericles and Cicero, an agora and a forum, a temple and a church, the Parthenon and the Colosseum". (Se pensiamo al passaggio del testimone tra Grecia e Italia non pensiamo a cose straordinarie e affascinanti e ricche di suggestione, come il rapporto tra Anchise ed Enea, Pericle e Cicerone, l'agora ed il foro, il tempio e la chiesa, il Partenone e il Colosseo.)

Grillo_1 (20:52) "We are here to understand, to simplify, to bring it out". (Noi siamo qui per capire, per semplificare, per portare fuori.)

Grillo_2 (05:46) "We want to stay in a Europe which is beautiful, diverse, with the French, with the Germans, we want to be among them because we are different and we are Italians!" (Vogliamo rimanere in Europa bella, diversa, con i francesi, con i tedeschi, vogliamo starci in mezzo a questa gente qua, perché siamo diversi, siamo italiani!)

A repetition is the repeated application of the same linguistic element. It is used as a persuasion techniques. The Italian politicians used this measure relatively often:

20 „Emfaza” [Entry], in: „Słownik języka polskiego PWN”, http://sjp.pwn.pl/slowniki/emfaza. html [access: 4.11.2015]. 
Renzi_1 (03:01) "I want to give you a specific example, first of all I want to give it to me”. (Voglio farvi un esempio concreto, voglio farvi innanzitutto a me.)

Renzi_1 (03:50) "We do not think about it when Greece and Italy are discussed in Europe, and we do not think about questions concerning the meaning of life...". (Non pensiamo a questo quando in Europa discutiamo di Grecia e Italia e non pensiamo nemmeno alle domande sul senso della vita...)

Renzi_1 (06:37) "We said that we have to implement our reforms, that we have to change bureaucracy, justice, the fiscal system, that we have to change the institutions". (Abbiamo detto che noi dobbiamo fare le nostre riforme, che noi dobbiamo cambiare la burocrazia, la giustizia, il sistema fiscale, che noi dobbiamo cambiare le istituzioni.)

Renzi_1 (08:37) "We do not want to judge the past, we are not interested in judging the past, we are interested in starting the future immediately". (Non chiediamo giudizio sul passato, non ci interessa giudicare il passato, ci interessa iniziare il futuro subito.)

Grillo_1 (11:44) "We need to assist in understanding what this system is. We need to assist in understanding in what kind of a world we live". (Dobbiamo far capire che cos'è questo sistema. Dobbiamo far capire che tipo del mondo viviamo.)

Grillo_1 (20:14) "We have changed the Italian parliament. We have changed Italian politics". (Abbiamo cambiato il parlamento italiano. Abbiamo cambiato la politica italiana.)

Grillo_1 (22:40) "They have never treated fiscal policy seriously. They have never treated information policy seriously. (Hanno mai preso sul serio la politica fiscale. Hanno mai preso sul serio la politica dell'informazione.)

Grillo_2 (02:29) "We are getting used to this putridity, perhaps we are getting used to it and we do not even see it...". (Ci stiamo abituando a questo marcio, forse ci stiamo abituando e non lo percepiamo neanche più...)

Grillo_2 (03:21) "Maybe Forza Italia or Forza Mafia, call it as you wish, will no longer exist ... maybe something will happen, this something ... something will happen!" (Magari Forza Italia o Forza Mafia, chiamatela come volete, non ci sarà più, ... forse succederà qualcosa, questo qualcosa ... succederà qualcosa!)

A repetition can also take a form of a confession (confessio): Grillo_1 (09:28) "I have changed my job, I have changed my mindset". (Ho cambiato il mio lavoro, ho cambiato la mia struttura mentale.)

Anaphora is a particular type of a repetition, and it is also used in persuasion. It is based on repeating the same word at the beginning of the following constituents of an utterance ${ }^{21}$ :

${ }^{21}$ See: E. Kujawska-Lis, „Dickensowskie anafory w polskim przekładzie”, Prace Językoznawcze 2009, Issue 11, Uniwersytet Warmińsko-Mazurski, pp. 115-117. 
Renzi_1 (07:05) "Italy comes here to ask Europe for the changes it cannot introduce on its own. Italy comes here to say that it is first to want the changes. Italy comes here to say that it believes in the European institutions, and comes to say it with conviction and determination". (L'Italia viene qui per chiedere all'Europa i cambiamenti che lei non è in grado di fare. L'Italia viene qui a dire che lei per prima viene a cambiare, viene qui a dire che lei crede nelle istituzioni europee e viene qui per dirlo con la convinzione e con la determinazione.)

Renzi_1 (13:00) "You represent great responsibility, you represent the light of the civilisation, you, as Europe, represent the civilisation of globalisation". (Voi rappresentate...grande responsabilità, voi rappresentate il faro di civiltà. Voi rappresentate come l'Europa la civilizzazione della globalizzazione.)

Renzi_1 (13:48) "If there is no reaction from Europe, if there is no reaction from you...". (Se non c'è la reazione dell'Europa, se non c'è la Vostra reazione...)

Anadiplosis is a "stylistic figure - it is an opening of a new sentence, a part of a sentence or a new line with a word used at the end of the preceding sentence or of the preceding line"22. Examples also can be found in the analysed speeches:

Renzi_1 (15:56) “... during our semester, during our semester, when the ASEM summit in Milan takes place ... ". (...durante il nostro semestre, durante il nostro semestre, quando incontreremo il vertice ASEM a Milano...)

Renzi_1 (16:32) "That is why, that is why there is no Italy which would ask for shortcuts ... “. (Ecco perché, ecco perché non c'è l'Italia che chiede scorciatoie...) Grillo_1 (02:00) "We came here, here, here ... from a press campaign, which was shameful information, shameful of him, where he was described, for example, as a terrible person, a homophobe, a racist, with peculiar behaviour, as a drunkard, an incredible thing”. (Siamo arrivati qua, qua, qua... da una campagna di stampa, dall'informazione vergognosa, vergognosa su di lui per esempio dove veniva dipinto come un uomo terribile, come un omofobo, come un razzista, come che ha i giri strani, come un ubriacone, una roba incredibile.)

Grillo_1 (04:55) "This Schulz, Schulz came to Italy to make a campaign using European money, that is the public money, and he made a campaign against me, against me, and I don't even know this person". (Questo Schulz, Schulz che è venuto in Italia a farsi la campagna, lui con $i$ soldi europei, quindi pubblici, e ha fatto la campagna contro di me, contro di me, che non lo conosco neanche.)

Grillo_1 (05:10) "Be careful Schulz, now I am here, I am here, Schulz. Now there are 17 of us, with me it's 18". (Stai attento Schulz, adesso sono qua, sono qua, Schulz. Adesso siamo qua, in 17, più io, in 18.)

${ }^{22}$ „Anadiploza” [Entry], in: „Słownik języka polskiego PWN”, http://sjp.pwn.pl/sjp/anadiploza;2549890 [access: 4.11.2015]. 
Grillo_1 (10:48) "We do not think anymore, we do not think, people are afraid to think". (Non pensiamo più, non pensiamo più, la gente ha paura di pensare.)

Grillo_1 (13:59) "The problem is we do not have a plan B, the problem is we do not have a plan B". (Il problema che non abbiamo piano B, il problema che non abbiamo piano B.)

Rhetorical questions, by definition, do not require any answer but rather indicate a problem, and emphasise the persuasiveness of the communication. This figure addresses the recipient's attention and cooperation. Politicians use both the interrogatio (it happens when the answer to the question is well known) and the subiectio (when the speaker asks themselves a question and answers it) ${ }^{23}$.

Renzi_1 (08:11) "Who remembers that we signed the Stability and Growth Pact?" (Chi si ricorda che abbiamo firmato il patto di stabilità e di crescita?)

Renzi_1 (08:52) "Do we still have a wish to restore the game or not? Do we still have the desire to be a part of the avant-garde or not? Abbiamo un desiderio o no di essere un'avanguardia?)

Grillo_1 (04:34) "Where is the power?" Who are these nominated people, not elected by anyone? (I poteri dove sono? Chi sono queste persone nominate, non elette da nessuno?)

Grillo_1 (06:06) "What kind of a monetary union have we created? I do not know. What kind of an economic union is this? ... What is this European economy? (Che tipo di unione monetaria ne abbiamo fatto? Io non lo so. Che tipo di unione economica è questa? ... Che cos'è questa economia europea?)

Grillo_1 (06:30) "Do we still need Europe? Is the money in the banks still useful? Do we still need rigour?" (Ci serve più Europa? Ci servono più soldi alle banche? Ci serve più rigore?)

Grillo_1 (16:31) "Where is the European Union? What is the European Union?" (Dove è l'Unione Europea? Cos'è l'Unione Europea?)

Grillo_1 (17:27) "Where are they going? Where labour costs less". (Dove vanno? Dove il lavoro costa meno.)

Grillo_2 (01:01) "What can we miss about the year 2014, which is ending? Renzi, his discourses? What can we regret? Is it the attack on democracy and on the constitution of two small political parties PD and PDL?" (Cosa potremo rimpiangere del 2014, che se ne va? Renzi, le balle di Renzi? Cosa potremo rimpiangere? Un attentato alla democrazia e alla costituzione di due partitelli: il PD e il PDL?)

Grillo_2 (06:07) "Why should we continue to think that we do not have a plan B?" (Perché continuare a pensare di non avere un piano B?)

${ }^{23}$ See: K. Felsner, H. Helbig, T. Manz, „Arbeitsbuch Lyrik”, Akademie Verlag GmbH, Berlin 2012, p. 182. 


\section{The Italian politicians' communicational situation vs. Habermas's "ideal speech situation"}

Do the analysed speeches of the politicians fulfil the conditions of the "ideal speech situation"? Do the applied linguistic persuasion measures influence achieving the conditions, which decide about acknowledging - or not - the politician's speech as a rational basis for legitimisation of the democratic political system? And if so, how does it happen?

Condition 1: equality between the discourse partners.

First person plural forms of the verbs, the personal pronoun we and the possessive pronoun our can indicate the equality of the sender and the receiver of the communication. The existence of imperative sentences, which take the form of duty-imposing sentences, as well as the existence of emphasis, also serve to achieve this condition. Taking into consideration other factors, apart form the persuasive ones, it has to be noticed that in the case of Berlusconi's speech in the streets of Rome and Grillo's speech summarising the year 2014, which was recorded in unlit rooms similar to the ancient catacombs, one cannot require the condition of equality between the discourse partners to be fulfilled. There is no discourse partner, these are examples of peculiar monologues of the politicians with present persuasive elements. On the other hand, the members of the European Parliament along with the chairperson of the session form rather a passive auditorium for the Prime Minister Renzi and Grillo - the leader of the Five Star Movement. This makes it impossible to achieve Condition 1. The sense of equality between the discourse partners, which is achieved by means of the persuasive measures, is illusory, doubtful.

Condition 2: the complete exposure of the deliberation processes.

Although it is difficult to research the orator's intentions, this condition, as far as I am concerned, is fulfilled within all four speeches: the speakers confront their feelings, views and emotions with themselves and with the audience. It can be proved on the basis of the numerously applied linguistic means of persuasion pointed out in the analysis, that is, among others, the rhetorical questions, emphasis or the volitional character of the utterances.

Condition 3: the temporary abandonment of power and domination relations.

This condition cannot be found in the analysed speeches of Berlusconi or Renzi. Nevertheless, Grillo in his speeches, because of the applied rhetoric of communication, identifies himself with the ordinary citizen and wishes to be perceived more as a humorist than a politician. It can be assumed that, to a considerable degree, in the speeches of the leader of MoVimento 5 Stelle there is this temporary abandonment of power and domination relations. The utterances in which there are duty-imposing sentences, create an illusive sense of community 
between the politician and the audience which is devoid of the power and domination relation.

Condition 4: the freedom to choose the topic of the discussion.

This condition is achieved in all of the analysed speeches.

\section{Conclusion}

The conducted analysis of these few selected public speeches of Italian politicians shows that the applied vocabulary, syntax, and rhetorical figures are the persuasive elements notably present in speech, used with the intention to convince the listener to adopt a certain point of view. Politicians are well aware of the mechanisms of communication theories and are capable of applying rhetorical figures in their communications. They want to obtain the recipient's approval for their own views. The analysis of Grillo's, Renzi's and Berlusconi's speeches exposes a high emotionality of communication. The dynamic, changing timbre and voice power, as well as the accompanying gesticulation, prove the high level of the emphatic nature of the discourse. Nevertheless, none of the analysed speeches fulfils all the discourse criteria which were described by Habermas, and that is why they cannot be perceived as a rational basis for legitimisation of the democratic political system. Appropriately applied linguistic persuasion creates the subjective impression of the allegedly existing "ideal speech situation", which was described by the philosopher. The issue of power legitimisation cannot be narrowed down only to the notions connected with the persuasiveness of the communication, although this subject is a crucial and necessary element in political communication. The rhetoric of the communication is vital, however, without the orator's proper ethos, it is not sufficient enough to gain social acceptance.

Grillo is a good comedian, who expresses populist slogans, rather than an economic expert. It does not stand in his way in voicing many new economic theories, allegedly solving the most important problems of the discipline within the country and in Europe. In his speeches it is not solid knowledge that emerges, but wit, gesticulation, and a multitude of rhetorical figures. On the other hand, Berlusconi is a politician who evokes strong emotions in Italy, for example, because of his suspicious connections with the criminal world, the unknown sources of his enormous wealth, and the sex scandals. His moral predispositions leave a lot to be desired. Renzi has been the Prime Minister for a relatively short time, and has not been able to deal with the high unemployment rate among young people or the ingoing masses of illegal immigrants from Africa.

It seems that the analysed speeches do not restrict the recipient's freedom sphere, and that they allow independent thinking, despite the high level of the 
persuasiveness of the communication. With respect to the earlier mentioned criteria of a good orator according to Aristotle or Cicero, Renzi, Berlusconi and Grillo are not always faithful to the truth and do not have the ideal intellectual and moral competences to be able to hold the public discourse. The ancient rhetoricians set high requirements even for the modern representatives of the political world, for whom public speeches are included in the mission they have been entrusted with and in their everyday work.

\section{Bibliography}

„Anadiploza” [Entry], in: „Słownik języka polskiego PWN”, http://sjp.pwn.pl/sjp/anadiploza;2549890 [access: 4.11.2015].

Arystoteles, „Etyka nikomachejska”, as cited in: Aristotelis, “Ethica Nicomachea”, recognovit F. Susemihl, Teubner, Lipsiae 1880.

Arystoteles, „Etyka wielka”, in: idem, „Dzieła wszystkie”, Vol. 5, transl. D. Gromska, Wydawnictwo Naukowe PWN, Warsaw 1996, pp. 338-344.

Baciak P., „Internet - Agora XXI wieku? Rozważanie w świetle teorii demokracji deliberatywnej autorstwa Jürgena Habermasa", Global Media Journal - Polish Edition 2006, No. 2 (2), pp. 136-139, http://globalmediajournal.collegium.edu.pl/artykuly/jesien\%202006/Baciak-Internet\%20-\%20Agora\%20XXI\%20wieku.pdf [access: 4.11.2015].

„Beppe Grillo: humorysta, bloger, polityk”, http://pl.euronews.com/2012/05/22/beppe-grillo-humorysta-bloger-polityk/ [access: 4.11.2015].

Capek-Habekovič R., Palaich S., "Parola a te!”, Heinle Cengage Learning, Boston 2009.

"Chi c'è dietro Beppe Grillo? Ritratto di Casaleggio, lo stratega 5Stelle", http://www.iltempo. it/politica/2012/10/01/chi-c-e-dietro-beppe-grillo-ritratto-di-casaleggio-lo-stratega5stelle-1.3130 [access: 11.02.2015].

Cyceron M.T., „O mówcy”, transl. B. Awianowicz, Wydawnictwo Antyk, Warsaw 2011.

Daconto C., "I 10 politici più importanti del 2014", http://www.panorama.it/news/politica/i-10-politici-piu-importanti-2014/ [access: 4.11.2015].

Dziurlikowska I., „Włoska prezydencja pod znakiem rozwoju”, http://www.uniaeuropejska.org/ wloska-prezydencja-pod-znakiem-rozwoju [access: 4.11.2015].

„Emfaza” [Entry], in: „Słownik języka polskiego PWN”, http://sjp.pwn.pl/slowniki/emfaza.html [access: 4.11.2015].

Felsner K., Helbig H., Manz T., „Arbeitsbuch Lyrik”, Akademie Verlag GmbH, Berlin 2012.

Fras J., „Komunikacja polityczna. Wybrane zagadnienia gatunków i języka wypowiedzi”, Wydawnictwo Uniwersytetu Wrocławskiego, Wroclaw 2005.

Gimmler A., "Deliberative Democracy, the Public Sphere and the Internet", Philosophy \& Social Criticism 2001, Vol. 27, pp. 21-39.

Habermas J., „Vorstudien und Ergänzungen zur Theorie des kommunikativen Handelns”, Frankfurt am Main 1984.

Kujawska-Lis E., „Dickensowskie anafory w polskim przekładzie”, Prace Językoznawcze 2009, Issue 11, Uniwersytet Warmińsko-Mazurski, pp. 115-133.

"Matteo Renzi, la mia storia. Chi sono", http://www.matteorenzi.it/chi-sono/ [access: 4.11.2015]. 
Kwintylian, „Kształcenie mówcy. Księgi I, II i X”, transl. and ed. M. Brożek, Ossolineum, Wroclaw 1951.

Nieć M., „Komunikowanie społeczne i media. Perspektywa politologiczna”, LEX Grupa Wolters Kluwer, Warsaw 2010.

Pisarek W., „Perswazja - jak ją widzą, jak ją piszą”, in: „Język perswazji publicznej”, ed. K. Mosiołek-Kłosińska, T. Zgółka, Wydawnictwo Poznańskie, Poznan 2003, pp. 9-17.

„Silvio Berlusconi”, http://ludzie.wprost.pl/sylwetka/Silvio-Berlusconi/ [access: 4.11.2015].

"The world's 50 most powerful blogs", http://www.theguardian.com/technology/2008/mar/09/ blogs [access: 4.11.2015].

Zdunkiewicz D., ,Językowe środki perswazji w homiliach (na przykładzie tekstów Jana Pawła II)”, in: „Język a kultura”, Vol. 4 „Funkcje języka i wypowiedzi”, ed. J. Bartmiński, R. Grzegorczykowa, Wiedza o Kulturze, Wroclaw 1991, pp. 149-157.

Żardecka-Nowak M., „Demokracja deliberatywna jako remedium na ponowoczesny kryzys legitymizacji władzy", Teka Komisji Politologii i Stosunków Międzynarodowych. Polska Akademia Nauk Oddziat w Lublinie 2008, Vol. III, pp. 29-40, http://www.pan-ol.lublin.pl/ wydawnictwa/TPol3/Zardecka.pdf [access: 4.11.2015].

http://archivio.internazionale.it/news/unione-europea/2014/07/02/il-discorso-integrale-di-matteorenzi-al-parlamento-europeo [access: 4.11.2015].

http://www.beppegrillo.it/videos/0_s49orvgm.php [access: 4.11.2015].

http://www.repubblica.it/2004/a/sezioni/politica/festaforza/discesa/discesa.html [access: 4.11.2015].

https://www.youtube.com/watch?v=cbkaEeG721Y [access: 4.11.2015].

https://www.youtube.com/watch?v=go4FPwf0aVI [access: 4.11.2015].

\section{Rafał Leśniczak}

\section{The Persuasiveness of a Message and the Problem of Legitimacy}

\section{(Summary)}

The author analyses several selected speeches of Italian politicians: the founder of the Forza Italia party, Silvio Berlusconi; the founder and leader of the Five Stars Movement, Beppe Grillo; and the current Prime Minister of Italy, Matteo Renzi. The study makes it possible to evaluate whether the conditions for the ideale Sprechsituation (the ideal speech situation) of Jürgen Habermas are fulfilled in analysing the public discourse. Particular attention will be given to the relationship between the persuasiveness of the communication and the problem of legitimacy.

Keywords: persuasiveness, political communication, the ideal speech situation, emphasis, the legitimacy of power. 